\title{
RETURN ON ASSETS DAN DETERMINASI FAKTOR-FAKTOR YANG MEMPENGARUHINYA (STUDI PADA BUS NON DEVISA PERIODE 2018-2019)
}

\author{
Nikmatul Azizah ${ }^{\mathbf{1}}$, Agung Eko Purwana ${ }^{2}$ \\ ${ }^{1,2}$ Institut Agama Islam Negeri Ponorogo, Indonesia \\ Email: azizah.mmn@gmail.com ${ }^{1}$
}

\begin{abstract}
Return on Assets (ROA) is important for banks. This is because ROA can be used to measure a bank's ability to make profits in general. In the period 2018-2019 there were problems in the financial statements where when Murabahah Financing and Revenue Sharing Financing increased ROA decreased and when NOM increased ROA decreased. The purpose of this study tested the effect of murabahah financing, revenue sharing financing and NOM on ROA on Bank Uumum Syariah Non-Foreign Exchange. The novelty of this research is in the form of research methods used, which have never previously been used with murabahah financing variables, revenue sharing financing and NOM together. This research is a type of quantitative research with panel data regression methods. The sample used amounted to 4 from Non-Foreign Exchange Sharia Commercial Banks using quarterly data for the period 2018-2019. The findings in this study stated that murabahah financing, revenue sharing and NOM partially had no effect on ROA. However, together murabahah financing, revenue sharing financing and NOM affect ROA. The amount of influence given by the three variables to the ROA is $95.34 \%$. Non-Foreign Exchange Sharia Commercial Bank can increase bank profits and maintain bank stability in financing and investment by increasing the three variables together.
\end{abstract}

Keywords: financing, income, profitability, panel data

Abstrak: Return on Assets (ROA) merupakan sesuatu yang penting bagi Bank. Hal ini dikarenakan ROA dapat digunakan untuk mengukur kemampuan bank dalam memperoleh keuntungan secara umum. Pada periode tahun 2018-2019 ditemukan permasalahan pada laporan keuangan dimana ketika Pembiayaan Murabahah dan Pembiayaan Bagi Hasil meningkat ROA menurun dan ketika NOM meningkat ROA mengalami penurunan. Tujuan penelitian ini menguji pengaruh pembiayaan murabahah, pembiayaan bagi hasil dan NOM terhadap ROA pada Bank Uumum Syariah Non Devisa. Kebaruan dari penelitian ini berupa metode penelitian yang digunakan, yang sebelumnya belum pernah digunakan dengan variabel pembiayaan murabahah, pembiayaan bagi hasil dan NOM secara bersama-sama. Penelitian ini berjenis penelitian kuantitatif dengan metode regresi data panel. Sampel yang digunakan berjumlah 4 dari Bank Umum Syariah Non Devisa dengan menggunakan data triwulan periode 2018-2019. Hasil penemuan dalam penelitian ini menyatakan bahwa pembiayaan murabahah, pembiyaan bagi hasil dan NOM secara parsial tidak berpengaruh terhadap ROA. Akan tetapi secara bersamasama pembiayaan murabahah, pembiayaan bagi hasil dan NOM berpengaruh terhadap ROA. Besarnya perngaruh yang diberikan ketiga varibel tersebut terhadap ROA sebesar 95,34\%. Bank Umum Syariah Non Devisa dapat meningkatkan keuntungan bank dan menjaga kestabilan bank dalam melakukan pembiayaan maupun investasi dengan meningkatkan ketiga variable tersebut secara bersama-sama.

Kata Kunci: Pembiayaan, Pendapatan, Profitabilitas, Data panel 


\section{PENDAHULUAN}

Perbankan Syariah di Indonesia berkembang pesat. Krisis keuangan global sebagai salah satu yang membuat keuangan Islam berkembang pesat. Selain dari masyarakat dunia, para pakar, dan pengamat kebijakan ekonomi tak hanya sekedar melirik ke arah perbankan syariah, mereka juga tertarik untuk menerapkan konsep syariah secara tepat. Fenomena tingkat profitabilitas yang diperoleh bank syariah di Indonesia pada saat ini sangat menggelitik, baik dari segi aset, investor, maupun masyarakat pada umumnya terutama yang menganut prinsip Syariah (Widayati, 2016). Perbankan Syariah berdampak pada masyarakat, terutama terkait produk pembiayaan. Salah satu pacuan perekonomian yang kuat dan menjadi solusi terbaik untuk mengatasi berbagai jenis masalah perekonomian yang muncul di masyarakat saat ini, terutama untuk UMKM atau usaha mikro (Hasan, 2014, hlm. 103).

Bank syariah harus memiliki kinerja manajemen yang sehat dan efisien untuk mendapatkan keuntungan yang sebesar-besarnya. Untuk itu diperlukan suatu rasio profitabilitas untuk mengetahui bagaimana kinerja dari bank tersebut dalam menghasilkan keuntungan dari keseluruhan asset. Salah satu indikator yang digunakan ialah Return on Assets (ROA). Return on Assets merupakan suatu pengukur kemampuan manajemen bank dalam memperoleh keuntungan secara umum (Desiana \& Africo, 2017, hlm. 26).

Oleh karena itu, Return on Assets sangat penting bagi bank syariah, jika Return on Assets bank semakin besar atau berkembang, maka semakin besar pula tingkat keuntungan yang dicapai oleh bank tersebut dan semakin baik posisi bank tersebut, dan sebaliknya jika Return on Assets semakin menurun tingkat keuntungan yang diperoleh bank akan rendah dan dapat menyebabkan kebangkrutan (Mawaddah, 2015, hlm. 246). Pentingnya Return on Assets mengakibatkan banyak penelitian dilakukan membahas kinerja keuangan tersebut (Apriyanti, Rahman, \& Maharani, 2021; Awintasari \& Nurhidayati, 2021; Indriwati \& Purwana, 2021; Riyanto \& Asakdiyah, 2020; Setyowati, 2020; Wahyuningsih, 2019).

Berdasarkan grafik tingkat Return on Assets di atas, terlihat bahwa pada triwulan II-2018 hingga triwulan I-2019. Return on Assets dari Bank Umum Syariah meningkat sampai dengan 2,56\%, yang berdampak pada peningkatan kinerja keuangan Bank Umum Syariah. Kemudian pada triwulan II tahun 2019 hingga triwulan IV tahun 2019 Return on Assets mengalami penurunan yang cukup signifikan dengan angka mencapai 2,44 \% . 
Alasan penurunan Return on Assets pada triwulan II tahun 2019 sampai triwulan IV tahun 2019 adalah karena pada triwulan tersebut berdasarkan data statistik dari OJK, kemampuan memperoleh keuntungan tahun 2019 tidak secepat tahun yang lalu. Karena permintaan kredit baru yang sedikit dan juga disebabkan oleh berbagai standar permainan yang lebih dibebankan dan berujung pada tergerusnya laba. Stabil atau sehatnya rasio Return on Assets mencerminkan stabilnya jumlah modal dan pendapatan bank. Kondisi bank syariah yang stabil akan meningkatkan kemampuan bank untuk menyalurkan pembiayaan, misalnya pembiayaan murabahah dan pembiayaan bagi hasil (Mawaddah, 2015, hlm. 247).

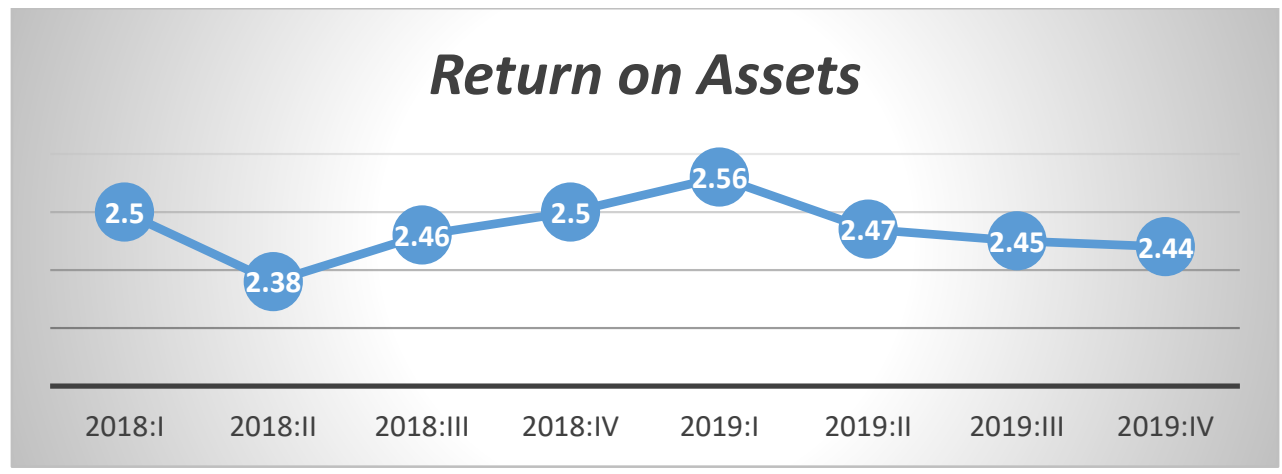

Sumber: Data Statistik Otoritas Jasa Kuangan

\section{Gambar 1. Perkembangan tingkat Return on Assets Bank Umum Syariah di} Indonesia Periode 2018- 2019

ROA dipengaruhi oleh dua faktor, yaitu faktor internal yang dapat dilihat dari indikator karakteristik laporan keuangan bank yang sebenarnya seperti produk pembiayaan (pembiayaan jual beli, pembiayaan bagi hasil, pembiayan sewa menyewa, dan pembiayaan akad pelengkap), NFP, CAR, ROE, DPK, BOPO, NOM, FDR, dan lain sebagainya. Sedangkan faktor eksternal bisa dilihat dari indikator makro ekonomi yang meliputi inflasi, tingkat suku bunga acuan, pertumbuhan ekonomi, perpajakan, sertifikat Indonesia, nilai tukar uang, dll (Riyadi \& Yulianto, 2014, hlm. 466).

Berdasarkan beberapa faktor yang telah digambarkan diatas, maka peneliti memfokuskan pada 3 komponen yang digunakan dalam penelitian ini yang akan mempengaruhi ROA yaitu Pembiayaan Murabahah, Pembiayaan Bagi Hasil, dan NOM. Pembiayaan Murabahah dapat mempengaruhi tingkat Return on Assets bank syariah. Pembiayaan Murabahah adalah perjanjian jual beli antara bank dan klien di mana bank 
syariah membeli barang yang diminta oleh klien, dan kemudian menawarkannya kepada klien yang bersangkutan sebesar harga perolehan ditambah dengan margin atau keuntungan yang disepakati dengan bank syariah dan klien. Semakin besar margin pembiayaan murabahah maka semakin tinggi pula keuntungan Return on Assets yang pada saat itu akan dialokasikan untuk bank syariah dan sebaliknya. Semakin rendah margin pembiayaan yang diperoleh maka semakin memburuknya Return on Assets yang diperoleh dan mengakibat kondisi laba suatu bank yang buruk (Muhamad, 2005, hlm. 23). Pembiayaan Murabahah berpengaruh signifikan terhadap Return on Assets. Apabila Pembiayaan Murabahah naik maka Return on Assets yang diperoleh juga meningkat (Sari \& Anshori, 2017, hlm. 6).

Selain pembiayaan murabahah yang digunakan bank syariah untuk pembiayaan dengan nasabah, bank syariah memiliki pembiayaan bagi hasil dimana pembiayaan ini digunakan untuk usaha kerja sama yang ditujukan untuk mendapat barang dan jasa sekaligus, dimana tingkat keuntungan bank ditentukan dari besarnya keuntungan oleh nisbah bagi hasil yang disepakati di awal (Arif, 2001, hlm. 50). Pembiayaan bagi hasil merupakan salah satu komponen penyusun asset pada perbankan syariah. Dari pengelolaan pembiayaan bagi hasil, bank syariah memperoleh bagian pendapatan sesuai proporsi disepakati dengan nasabah. Pendapatan yang diperoleh akan mempengaruhi besarnya keuntungan yang diperoleh bank (Muhamad, 2005, hlm. 35). Besar kecilnya keuntungan yang diperoleh bank syariah akan mempengaruhi profitabilitas yang dicapai. Semakin tinggi pembiayaan mudharabah dan pembiayaan musyarakah maka semakin tinggi profitabilitas bank umum syariah yang diporposikan dengan Return on Assets (Rahman \& Rochmanika, 2012, hlm. 6).

Faktor-faktor yang digunakan selain jenis pembiayaan di Bank Syariah juga menggunakan variabel Net Operating Margin. Net Operating Margin mempengaruhi tingkat Return on Assets bank syariah, dimana proporsi ini digunakan untuk menggambarkan pendapatan operasional bersih sehingga mampu diketahui kemampuan rata-rata aktiva produktif dalam menghasilkan keuntungan (Ihsan, 2013, hlm. 101). Semakin tinggi Net Operating Margin, semakin tinggi Return on Assets yang diperoleh, yang berati akan meningkatkan pendapatan yang diperoleh bank dari aktiva produktif tersebut sehingga kinerja keuangan semakin bertambah atau meningkat. Begitu juga sebaliknya, semakin rendah Net Operating Margin bank, semakin rendah Return on Assets sehingga kinerja bank berkurang atau menurun (Sudarwantoro, 2014, hlm. 3). 
Berdasarkan pemaparan diatas, permasalahan Pembiayaan Murabahah, Pembiayaan Bagi Hasil, dan Net Operating Margin di Bank Umum Syariah Non Devisa perlu dikaji lebih lanjut untuk mengatahui bagaimana pengaruhnya terhadap Return on Assets pada Bank Umum Syariah Non Devisa.

\section{TINJAUAN LITERATUR}

\section{Return on Assets (ROA)}

Return on Assets adalah rasio yang menggambarkan kemampuan bank dalam mengelola dana yang diinvestasikan dalam keseluruhan asset yang menghasilkan keuntungan. ROA merupakan gambaran efisiensi bank dalam mengelola dana sehingga menghasilkan keuntungan. ROA mampu mengukur kapasitas perusahaan untuk menghasilkan keuntungan pada masa lampau kemudian diproyeksikan di masa yang akan datang (Suwiknyo, 2016, hlm. 146). Seperti yang diindikasikan oleh Mardiyanto, ROA merupakan gambaran yang digunakan untuk mengukur kemampuan perusahaan dalam menghasilkan keuntungan yang berasal dari aktivitas investasi.

ROA adalah suatu jenis rasio profitabilitas yang diharapkan dapat mengukur kemampuan perusahaan dengan keseluruhan dana yang ditanamkan dalam aktiva yang digunakan perusahaan untuk menghasilkan keuntungan (Pravasanti, 2018). Nilai ROA yang semakin tinggi angkanya, semakin efektif suatu perusahaan atau bank syariah dalam menggunakan aktivanya untuk memperoleh keuntungan, sehingga nilai perusahaan meningkat. Rasio ROA yang tinggi menunjukkan produktivitas dan efektivitas pengelolaan asset yang berimplikasi pada peningkatan. Jadi semakin tinggi nilai Return on Assets menunjukkan bahwa kinerja keuangan perusahaan semakin membaik (Mawaddah, 2015, hlm. 246). Berdasarkan ketentuan BI standar ROA yang baik adalah sebesar 1,5 \% meskipun bukan suatu keharusan (Dendawijaya, 2009, hlm. 68).

\section{Pembiayaan Murabahah}

Pembiayaan atau financing adalah pendanaan yang diberikan oleh suatu pihak kepada pihak lain untuk mendukung investasi yang telah direncanakan, baik dilakukan sendiri maupun lembaga. Secara keseluruhan, pembiayaan adalah pendanaan yang dikeluarkan untuk mendukung investasi yang telah direncanakan. Murabahah berasal dari kata ribhu yang artinya keuntungan karena dalam transaksi jual beli bank menyebutkan jumlah keuntungan (margin/ mark up) (Antonio, 2001, hlm. 42). 
Murabahah merupakan jual beli yang mengharuskan penjual memberikan data kepada pembeli tentang biaya yang dikeluarkan untuk mendapatkan komoditas (harga pokok pembelian) dan tambahan profit yang diinginkan tercermin dalam biaya penjualan dan pembiayaan dari kegiatan usaha yang memiliki risiko yang tinggi (Setiawan \& Indriani, 2016).

Pembiayaan Murabahah adalah pembiayaan dana dari pemilik modal, baik Lembaga Keuangan Syariah Non Bank maupun Bank Syariah kepada nasabah untuk membeli barang dengan menegaskan harga belinya barang dan pembeli (nasabah) akan membayarnya dengan harga yang lebih, sebagai keuntungan pemilik modal sesuai yang disepakati bersama. Harga tidak boleh berubah sepanjang akad dan apabila terjadi kesulitan membayar, dapat dilakukan restrukrusisasi dan kalau tidak membayar karena lalai dapat dikenakan denda (Muljono, 2015, hlm. 143). Definisi operasional pembiayaan murabahah yang dipergunakan oleh UU No. 21 Tahun 2008 adalah Akad pembiayaan suatu barang dengan menegaskan harga belinya kepada pembeli dan pembeli membayarnya dengan harga yang lebih sebagai keuntungan yang disepakati (Hakim, 2019, hlm. 227).

\section{Pembiayaan Bagi Hasil}

Konsep pembiayaan bagi hasil berlandaskan pada beberapa prinsip dasar, khususnya: pembiayaan bagi hasil tidak berarti meminjamkan uang tunai tetapi investasi partisipasi dalam usaha. Pembiayaan dengan prinsip bagi hasil digunakan untuk usaha kerja sama yang ditujukan untuk mendapatkan barang dan jasa sekaligus, dimana tingkat keuntungan bank ditentukan dari besarnya keuntungan usaha sesuai dengan prinsip bagi hasil (Arif, 2001, hlm. 50).

Pada produk bagi hasil keuntungan ditentukan oleh proporsi nisbah bagi hasil yang disepakati sebelumnya. Secara umum akad bagi hasil dibedakan menjadi dua jenis, yaitu akad Mudharabah dan akad Musyarakah, namun di dalamnya terdapat muzaraah dan musaqoh meskipun jarang digunakan oleh Bank Syariah, khususnya di Indonesia (Umam \& Utomo, 2016). Sebagaimana dalam dunia perbankan, menghitung pembiayaan bagi hasil adalah jumlah total pembiayaan musyarakah + pembiayaan mudharabah.

Mudharabah adalah kerja sama antara dua pihak atau lebih lebih, pengelola modal (shahibul maal) mempercayakan sejumlah modal kepada pengelola (mudharib) dengan suatu perjanjian pembagian keuntungan. Sementara kerugian apabila bukan oleh 
kelalaian si pengelola maka kerugian ditanggung oleh si pemilik modal, namun apabila pengelola dengan sengaja melakukan kecurangan atau kelalaian maka pengelola harus bertanggung jawab atas kerugian tersebut (Arif, 2001, hlm. 52). Wirdyaningsi mendefinisikan mudharabah adalah akad antara pihak pemilik modal (shahibul maal) dengan pengelola (mudharib) untuk memperoleh pendapatan atau keuntungan (Perwantaatmadja, Dewi, Barlinti, \& Wirdyaningsih, 2005, hlm. 105).

Sedangkan Musyarakah adalah kerja sama antara dua pihak atau lebih untuk melakukan suatau usaha tertentu, yang masing-masing pihak memberikan kontribusi dana dengan kesepakatan bahwa keuntungan dan risiko akan ditanggung bersama sesuai kontribusi dana dan kesepakatan. Akad musyarakah adalah transaksi penanaman dana dari dua atau lebih pemilik dana atau barang untuk menjalankan usaha tertentu sesuai syariah dengan pembagian hasil usaha antara kedua belah pihak berdasarkan nisbah yang telah disepakati, sedangkan pembagian kerugian berdasarkan porsi modal masing-masing (Wardiyah, 2019, hlm. 196).

\section{Net Operating Margin}

Net Operating Margin adalah rasio utama rentabilitas pada bank syariah untuk menentukan kemampuan aktiva produktif dan menghasilkan laba. Kestabilan NOM harus dijaga, jika NOM rendah maka tingkat rentabilitas juga akan rendah, yang artinya keuntungan yang diperoleh akan sedikit (Suryanto \& Susanti, 2020, hlm. 34). NOM juga dapat dikategorikan sebagai rasio rentabilitas untuk mengatahui kemampuan aktiva produktif dalam menghasilkan laba melalui perbandingan pendapatan operasional dan beban operasional dengan rata-rata aktiva produktif. Net Operating Margin berasal dari selisih antara pendapatan penyaluran dana setelah bagi hasil dengan beban operasional dibagi rata-rata aktiva produktif. Net Operating Margin adalah rasio untuk menggambarkan pendapatan operasional bersih sehingga diketahui kemampuan rata-rata aktiva produktif dalam menghasilkan laba (Widiawati, 2019, hlm. 38).

Bank syariah tidak mengunakan sistem bunga seperti bank konvensional, maka Surat Edaran Bank Indonesia No.9/24/Dbs tahun 2007 menyebutkan bahwa bank syariah memiliki nilai NOM diatas 3\%. Hal ini menunjukkan bahwa bank Syariah memiliki penilaian rentabilitas yang tinggi sehingga dapat mengantisipasi potensi risiko kerugian serta dapat meningkatkan keutungan bank. Semakin tinggi Net Operating Margin suatu perusahaan atau bank maka semakin tinggi pula Return on Asset perusahaan atau bank 
tersebut, yang berati kinerja keuangan tersebut semakin baik atau berkembang. Selain itu sebaliknya, semakin rendah NOM bank syariah atau perusahaan menyebabkan penurunan ROA sehingga kinerja bank syariah berkurang atau memburuk (Widiawati, 2019, hlm. 40).

\section{METODE PENELITIAN}

Penelitian ini menggunakan metode kuantitatif dengan desain penelitian asosiatif. Variable bebas terdiri dari PM $\left(\mathrm{X}_{1}\right), \mathrm{PBH}\left(\mathrm{X}_{2}\right)$ dan NOM $\left(\mathrm{X}_{3}\right)$ sedangkan variable terikat yang digunakan adalah ROA (Y). Penelitian ini menggunakan data triwulan Bank Umum Syariah Non Devisa periode tahun 2018-2019 yang diperoleh melalui www.ojk.go.id dan www.bi.go.id. Bank Umum Syariah Non Devisa tersebut antara lain Bank BCA Syariah, Bank Panin Dubai Syariah, Bank Victoria Syariah, dan Bank Jabar Banten Syariah.

Data yang diperoleh selanjutnya dianalisis dengan analisis regresi data panel dengan tahapan uji statistik deskriptif, pemilihan model terbaik, uji asumsi klasik, model regresi data panel (uji parsial (uji t), uji simultan (uji F) dan koefisien determinasi $\left(\mathrm{R}^{2}\right)$ ). Persamaan model regresi data panel pada penelitian ini sebagai berikut

$$
\mathrm{ROA}_{i t}=\boldsymbol{B}_{0 \mathrm{i}}+\boldsymbol{B}_{1} \mathrm{PM}_{1 \mathrm{it}}+\boldsymbol{B}_{2} \mathrm{PBH}_{2 \mathrm{it}}+\boldsymbol{B}_{3} \mathrm{NOM}_{3 i t}+\mathrm{e}_{\mathrm{it}}
$$

Berdasarkan tujuan penelitian, hipotesis yang digunakan adalah $\mathrm{H}_{1}=$ Pembiayaan Murabahah memberikan pengaruh positif dan signifikan pada Return on Assets Bank Umum Syariah Non Devisa.

$\mathrm{H}_{2}=$ Pembiayaan Bagi Hasil memberikan pengaruh positif dan signifikan pada Return on Assets Bank Umum Syariah Non Devisa $\mathrm{H}_{3}=$ Net Operating Margin memberikan pengaruh positif dan signifikan pada Return on Assets Bank Umum Syariah Non Devisa

\section{HASIL DAN PEMBAHASAN}

\section{Uji Statistik Deskriptif}

Hasil statistik deskriptif pada Tabel 1 memperlihatkan bahwa masing-masing variable terdiri dari 32 sampel. Return on Assets (ROA) memiliki nilai rata-rata 0,45\% dimana nilai minimumnya adalah $0,02 \%$ dan nilai maksimumnya adalah $1,17 \%$. Pembiayaan Murabahah (PM) memiliki nilai rata-rata 4.675.602,10 juta rupiah dengan 
nilai minimum sebesar 262.445 juta rupiah dan maksimum sebesar 18.757 .429 juta rupiah.

Tabel 1. Statistik Deskriptif

\begin{tabular}{lrrrrr} 
Variabel & N & \multicolumn{1}{c}{ Rata-rata } & \multicolumn{1}{c}{ Max } & \multicolumn{1}{c}{ Min } & \multicolumn{1}{c}{ Stdev } \\
\hline ROA (\%) & 32 & 0,45 & 1,17 & 0,02 & 0,35 \\
\hline PM (Juta rupiah) & 32 & 4675602,10 & 18757429 & 262445 & 5751019,45 \\
\hline PBH (Juta rupiah) & 32 & 3745229,35 & 11797117 & 838533 & 2937053,25 \\
\hline NOM (\%) & 32 & 0,22 & 1,24 & $-0,97$ & 0,55 \\
\hline
\end{tabular}

Sumber: Data Diolah (2021)

Pembiayaan Bagi Hasil (PBH) memiliki nilai rata-rata 3.745.229,35 juta rupiah dengan nilai minimum sebesar 838.533 juta rupiah dan maksimum sebesar 11.797.117 juta rupiah. Net Operating Margin (NOM) memiliki nilai rata-rata 0,22 \% dimana nilai minimumnya adalah $-0,97 \%$ dan nilai maksimumnya adalah $1,24 \%$.

\section{Pemilihan Model Terbaik}

Untuk mendapatkan model yang terbaik pada regresi data panel dilakukan pengujian Chow dan pengujian Hausman. Dengan pengujian ini diperoleh satu model terbaik diantara Model Common Effects, Fixed Effects dan Random Effects.

Tabel 2. Hasil Pengujian Chow

\begin{tabular}{cccc}
\hline Effects Test & Stat & df & Sig. \\
\hline Cross-section $\mathrm{F}$ & 23,08 & $(3,25)$ & 0,00 \\
\hline Cross-section $\chi^{2}$ & 42,46 & 3 & 0,00 \\
\hline
\end{tabular}

Sumber: Data diolah (2021)

Tabel 3. Hasil Pengujian Hausman

\begin{tabular}{cccc}
\hline Test Summary & $\chi_{\text {stat }}^{2}$ & $\chi_{d f}^{2}$ & Sig. \\
\hline Cross-section random & 69,24 & 3 & 0,00 \\
\hline
\end{tabular}

Sumber: Data diolah (2021)

Tabel 2 menunjukkan hasil pengujian Chow dengan nilai sig (Cross-section F) sebesar $0,00<0,05$ sehingga model yang terpilih pada pengujian ini adalah model fixed effects. Hasil pengujian Hausman pada Tabel 3 menunjukkan nilai sig $\left(\chi_{\text {stat }}^{2}\right)$ sebesar $0,00<0,05$ sehingga model yang terpilih adalah model fixed effects. Berdasarkan hasil 
pengujian Chow dan pengujian Hausman dapat disimpulkan bahwa model regresi panel terbaik pada penelitian ini adalah model fixed effects.

\section{Uji Asumsi Klasik}

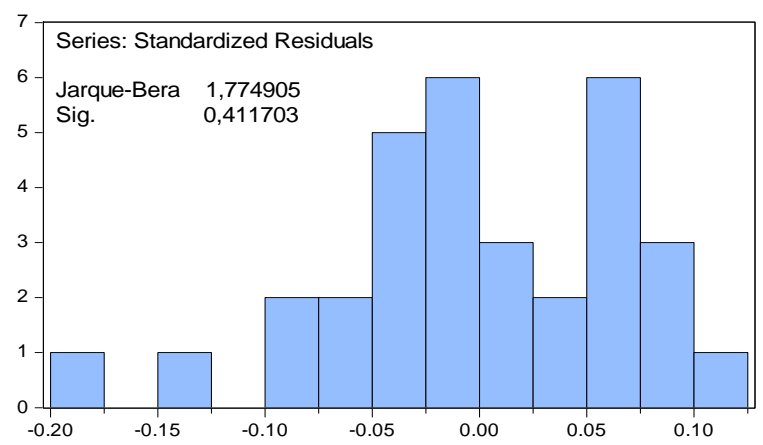

Gambar 1. Hasil Pengujian Normalitas

Hasil pengujian normalitas pada Gambar 1 memperlihatkan bahwa nilai sig sebesar 0,411703 lebih dari 0,05 yang menunjukkan bahwa residual pada penelitian ini berdistribusi normal. Hasil pengujian autokorelasi dengan metode Breusch-Godfrey pada Tabel 4 memperlihatkan bahwa nilai Sig $\left(\mathrm{Obs}^{2}\right)$ adalah 0,359 yang menunjukkan bahwa tidak terjadi autokorelasi pada model (autokorelasi terpenuhi).

\section{Tabel 4. Hasil Pengujian Autokorelasi}

\begin{tabular}{llll}
\hline Fhitung $_{\text {hig. }}$ & 0,888 & Sig. & 0,423 \\
\hline Obs $_{\text {hitung }}(2,26)$ & Sig. $\chi^{2}(2)$ & 0,359
\end{tabular}

Sumber: Data diolah (2021)

Tabel 5. Hasil Pengujian Heteroskedastisitas

\begin{tabular}{llll}
\hline Fhitung & 1,639 & Sig. $F_{\text {hitung }}(3,28)$ & 0,203 \\
\hline Obs*R $^{2}$ & 4,788 & Sig. $\chi^{2}(3)$ & 0,189 \\
\hline Scaled explained SS & 5,389 & Sig. $\chi^{2}(3)$ & 0,145 \\
\hline
\end{tabular}

Sumber: Data diolah (2021)

Tabel 6. Hasil Pengujian Multikolinieritas

\begin{tabular}{cccc}
\hline & PM & PBH & NOM \\
\hline PM & 1 & $-0,40$ & $-0,08$ \\
\hline PBH & $-0,40$ & 1 & $-0,18$ \\
\hline NOM & $-0,08$ & $-0,18$ & 1 \\
\hline
\end{tabular}

Sumber: Data diolah (2021) 
Pengujian Heteroskedastisitas dilakukan dengan metode Glejser dan ditunjukkan pada Tabel 5. Dari hasil tersebut, diperoleh nilai Sig (Obs $\mathrm{R}^{2}$ ) sebesar 0,189 yang artinya tidak terjadi heteroskedastisitas (pengujian heteroskedastisitas terpenuhi). Tabel 6 yang merupakan hasil pengujian multikolinieritas menghasilkan nilai korelasi kurang dari 0,8 sehingga tidak terdapat multikolinieritas. Hasil pengujian asumsi klasik menunjukkan bahwa semua pengujian telah terpenuhi.

\section{Model Regresi Data Panel}

Tabel 7. Koefisien Model Regresi Data Panel

\begin{tabular}{cccc}
\hline Variabel & Koef & thitung & Sig. \\
\hline C & 0,452 & 3,202 & 0,004 \\
\hline PM? & $3,01 \mathrm{E}-08$ & 0,751 & 0,460 \\
\hline PBH? & $-2,72 \mathrm{E}-08$ & $-1,018$ & 0,318 \\
\hline NOM? & 0,155 & 1,765 & 0,090
\end{tabular}

Sumber: Data diolah (2021)

Persamaan yang dapat dibentuk dari hasil yang ditunjukkan pada Tabel 7 sebagai berikut.

$$
R O A_{i t}=0,452+3,01 * 10^{-8} P M_{i t}-2,7 * 10^{-8} P B H_{i t}+0,155 N O M_{i t}+e
$$

Dari persamaan regresi model regresi data panel dan hasil uji t dapat dijelaskan bahwa:

a. Konstanta sebesar 0,452 memberikan arti jika PM, PBH, dan NOM pada observasi kei dan periode ke-t adalah 0, maka nilai ROA adalah $0,452 \%$.

b. PM memiliki nilai koefisien $3,01 * 10^{-8}$ artinya jika nilai PM pada observasi ke-i dan

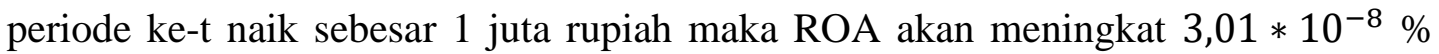
dengan asumsi variable lain pada observasi ke-i dan periode ke-t tidak berubah/tetap. PM dengan nilai sig=0,460 $>0,05$ menunjukkan bahwa PM tidak berpengaruh positif terhadap ROA.

c. PBH memiliki nilai koefisien $-2,7 * 10^{-8}$ artinya jika nilai PBH pada observasi ke-i dan periode ke-t naik sebesar 1 juta rupiah maka ROA akan meningkat $-2,7 * 10^{-8}$ \% dengan asumsi variable lain pada observasi ke-i dan periode ke-t tidak berubah/tetap. $\mathrm{PBH}$ dengan nilai sig=0,318 > 0,05 menunjukkan bahwa $\mathrm{PBH}$ tidak berpengaruh positif terhadap ROA. 
d. NOM memiliki nilai koefisien 0,155 artinya jika nilai NOM pada observasi ke-i dan periode ke-t naik sebesar $1 \%$ maka ROA akan meningkat $0,155 \%$ dengan asumsi variable lain pada observasi ke-i dan periode ke-t tidak berubah/tetap. NOM dengan nilai sig $=0,090>0,05$ menunjukkan bahwa NOM tidak berpengaruh positif terhadap ROA.

Tabel 8. Hasil Uji Simultan (Uji F)

\begin{tabular}{cc}
\hline \multicolumn{2}{c}{ Cross-section fixed (Variabel Dummy) } \\
\hline Sig.(Fhitung)
\end{tabular}

Sumber: Data diolah (2021)

Tabel 8 memperlihatkan nilai Sig ( $F_{\text {hitung }}$ ) 0,000<0,05 yang artinya PM, PBH, dan NOM berpengaruh pada ROA secara simultan. Nilai Adj $\mathrm{R}^{2}$ sebesar 0,953327 artinya kontribusi PM, PBH, dan NOM pada ROA sebesar 95,34\% dan sisanya 4,66\% dipengaruhi oleh variabel lain diluar model.

Tabel 9. Konstanta Model Fixed Effects Setiap Bank

\begin{tabular}{cc}
\hline \multicolumn{2}{c}{ Fixed Effects (Cross) } \\
\hline BCAS & 0,462 \\
\hline BJBS & $-0,113$ \\
\hline BPDS & $-0,086$ \\
\hline BVS & $-0,263$ \\
\hline
\end{tabular}

Sumber: Data diolah (2021)

Dari nilai konstanta pada Tabel 9 dapat dibentuk model untuk setiap Bank Umum Syariah Non Devisa sebagai berikut.

a. Model Regresi pada Bank BCA Syariah

Konstanta model regresi sebesar $0,452+0,462=0,914$ menunjukkan bahwa ketika nilai PM, PBH, dan NOM Bank BCA Syariah pada periode ke-t adalah 0 maka nilai ROA adalah 0,914 dengan persamaan modelnya sebagai berikut

$$
R O A_{t}=0,914+3,01 * 10^{-8} \mathrm{PM}_{t}-2,7 * 10^{-8} \mathrm{PBH}_{t}+0,155 \mathrm{NOM}_{t}+e
$$

b. Model Regresi pada Bank Jabar Banten Syariah

Konstanta model regresi sebesar 0,452-0,113=0,339 menunjukkan bahwa ketika nilai PM, PBH, dan NOM Bank Jabar Banten Syariah pada periode ke-t adalah 0 maka nilai ROA adalah 0,339 dengan persamaan modelnya sebagai berikut 


$$
R O A_{t}=0,339+3,01 * 10^{-8} P_{t}-2,7 * 10^{-8} P_{B} H_{t}+0,155 N O M_{t}+e
$$

c. Model Regresi pada Bank Panin Dubai Syariah

Konstanta model regresi sebesar 0,452-0,086=0,366 menunjukkan bahwa ketika nilai PM, PBH, dan NOM Bank Panin Dubai Syariah pada periode ke-t adalah 0 maka nilai ROA adalah 0,366 dengan persamaan modelnya sebagai berikut.

$$
R O A_{t}=0,366+3,01 * 10^{-8} P_{t}-2,7 * 10^{-8} P_{B} H_{t}+0,155 N O M_{t}+e
$$

d. Model Regresi pada Bank Victoria Syariah

Konstanta model regresi sebesar 0,452-0,263=0,189 menunjukkan bahwa ketika nilai PM, PBH, dan NOM Bank Victoria Syariah pada periode ke-t adalah 0 maka nilai ROA adalah 0,189 dengan persamaan modelnya sebagai berikut.

$$
R O A_{t}=0,189+3,01 * 10^{-8} P_{t}-2,7 * 10^{-8} \mathrm{PBH}_{t}+0,155 \mathrm{NOM}_{t}+e
$$

Persamaan model regresi masing-masing Bank Umum Syariah yang terbentuk mengindikasikan bahwa pada kondisi yang sama yaitu pada saat nilai PM, PBH, dan NOM periode ke-t bernilai 0 Bank BCA Syariah mampu memberikan nilai ROA paling tinggi dibandingkan dengan Bank Syariah yang lain. Sedangkan nilai ROA paling rendah adalah Bank Victoria Syariah.

\section{Pengaruh PM, PBH dan NOM terhadap ROA}

Berdasarkan hasil analisis data, diketahui bahwa penelitian ini menyatakan PM, $\mathrm{PBH}$, dan NOM secara parsial tidak berpengaruh pada ROA. Akan tetapi PM, PBH, dan NOM secara simultan berpengaruh pada ROA. Penurunan return on assets yang disebabkan oleh kurangnya pembiayaan murabahah dan pembiayaan bagi hasil dan diikuti oleh penurunan net operating margin secara bersama-sama, penelitian ini diperkuat penelitian yang telah dilakukan sebelumnya oleh Dedeh Rahmawati (Rahmawati, 2017), Geofani Nursucia Widyawati (Widyawati, 2017), dan Cut Faradilla dkk (Faradilla, Arfan, \& Shabri, 2017). Penurunan return on assets berdampak pada kemampuan bank dalam menghasilkan laba menjadi berkurang. Apalagi perkembangan perekonomian khususnya dunia perbankan semakin pesat maka dari itu, mengakibatkan persaingan antar bank semakin ketat untuk meningkatkan daya saing diberbagi sektor termasuk tingkat profitabilitas yang dapat diukur dengan return on assets. Kenaikan keuntungan pada suatu bank, sangat berpengaruh terhadap return on assets dikarenakan semakin tinggi return on assets semkain baik posisi bank dan dapat meningkatakan profitabilitas yang diukur dengan return on assets. 
Kondisi bank syariah yang stabil dalam menghasilkan keuntungan yang salah satunya diukur dengan return on assets maka berdampak pada nasabah yang melakukan pembiayaan maupun investasi. Investasi yang semakin banyak dapat meningkatkan pendapatan bank yang berakibat pada return on assets juga meningkat pada bank umum syariah terutama bank umum syariah non devisa. Keuntungan yang digunakan untuk menambah laba nantinya yang digunakan sebagai investasi.

Oleh karena itu, sebaiknya bank umum syariah non devisa harus mampu menggunakan ketiga variabel yang meliputi pembiayaan murabahah, pembiayaan bagi hasil dan net operating margin secara bersama-sama untuk meningkatkan return on assets tanpa mengesampingkan salah satu dari variabel tersebut mempengaruhi pendapatan bank syariah dan secara langsung meningkatkan serta memperbaiki return on assets dari bank umum syariah non devisa yang semakin menurun.

\section{KESIMPULAN}

Hasil penelitian menunjukkan bahwa pembiayaan murabahah, pembiayaan bagi hasil dan net operating margin tidak berpengaruh pada return on assets secara parsial. Akan tetapi, pembiayaan murabahah, pembiayaan bagi hasil dan net operating margin berpengaruh pada return on assets secara simultan. Hasil ini menegaskan bahwa ketiga variabel tersebut memiliki pengaruh yang tinggi bagi pendapatan Bank Umum Syariah Non Devisa dan secara langsung dapat meningkatkan Return on Assets. Bank Umum Syariah harus mampu menggunakan ketiga variabel tersebut tanpa mengesampingkan salah satunya untuk meningkatkan keuntungan bank dan menjaga kestabilan bank dalam melakukan pembiayaan maupun investasi. Untuk meningkatkan hasil penelitian yang lebih baik lagi diharapkan bagi peneliti selanjutnya menambahkan faktor-faktor lain yang digunakan untuk varibel independen yang mempengaruhi return on assets pada bank umum syariah non devisa selain yang digunakan pada penelitian ini.

\section{REFERENSI}

Antonio, M. S. (2001). Bank Syariah: Dari Teori ke Praktik. Jakarta: Gema Insani. Apriyanti, R., Rahman, A. A., \& Maharani, S. (2021). EMPIRICAL STUDIES OF THE EFFECT OF OPERATIONAL COSTS AND OPERATING INCOME, FINANCING TO DEPOSIT RATIO AGAINST RETURN ON ASSET WITH NON-PERFORMING FINANCING AS INTERVENING VARIABLES IN SHARIA BANK INDONESIA 2013-2020. Niqosiya: Journal of Economics and Business Research, 1(1), 21-36. https://doi.org/10.21154/niqosiya.v1i1.78 
Arif, M. N. R. A. (2001). Dasar-Dasar Pemasaran Bank Syariah. Bandung: Alfabeta.

Awintasari, L., \& Nurhidayati, M. (2021). PENGARUH NON PERFORMING FINANCING, CAPITAL ADEQUACY RATIO, BEBAN OPERASIONAL PENDAPATAN OPERASIONAL DAN NET IMBALAN TERHADAP RETURN ON ASSETS (STUDI PADA BANK MAYBANK SYARIAH PERIODE 2012-2019). Niqosiya: Journal of Economics and Business Research, 1(1), 78-93. https://doi.org/10.21154/niqosiya.v1i1.108

Dendawijaya, L. (2009). Manajemen Perbankan. Jakarta: Ghalia Indonesia.

Desiana, L., \& Africo, F. (2017). Analisis Laporan Keuangan (Teori dan Pemahaman Materi). Palembang: Noerfikri.

Faradilla, C., Arfan, M., \& Shabri, M. (2017). PENGARUH PEMBIAYAAN MURABAHAH, ISTISHNA, IJARAH, MUDHARABAH DAN MUSYARAKAH TERHADAP PROFITABILITAS BANK UMUM SYARIAH DI INDONESIA. Jurnal Administrasi Akuntansi: Program Pascasarjana Unsyiah, 6(3). Diambil dari http://jurnal.unsyiah.ac.id/JAA/article/view/8775

Hakim, A. A. (2019). Fiqih Perbankan Syariah. Bandung: PT Refika Aditama.

Hasan, N. I. (2014). Perbankan Syariah. Jakarta: GP Press Group.

Ihsan, D. N. (2013). Analisis Laporan Keuangan Kinerja Perbankan Syariah. Banten: UIN Jakarta Press.

Indriwati, L., \& Purwana, A. E. (2021). PENGARUH CAPITAL ADEQUACY RATIO, INFLASI, DAN GROSS DOMESTIC PRODUCT TERHADAP RETURN ON ASSETS (STUDI PADA BANK UMUM SYARIAH NON DEVISA DI INDONESIA PERIODE TAHUN 2018-2020). Niqosiya: Journal of Economics and Business Research, 1(1), 110-122. https://doi.org/10.21154/niqosiya.v1i1.90

Mawaddah, N. (2015). Faktor-Faktor Yang Mempengaruhi Profitabilitas Bank Syariah. ETIKONOMI, 14(2), 241-256. https://doi.org/10.15408/etk.v14i2.2273

Muhamad. (2005). Manajemen Pembiayaan Bank Syariah. Yogyakarta: Akademi Manajemen Perusahaan YKPN.

Muljono, D. (2015). Buku Pintar Akuntansi Perbankan dan Lembaga Keuangan Syariah. Yogyakarta: Andi.

Perwantaatmadja, K., Dewi, G., Barlinti, Y. S., \& Wirdyaningsih. (2005). Bank dan Asuransi Islam di Indonesia. Jakarta: Kencana.

Pravasanti, Y. A. (2018). Pengaruh NPF dan FDR Terhadap CAR dan Dampaknya Terhadap ROA Pada Perbankan Syariah Di Indonesia. Jurnal Ilmiah Ekonomi Islam, 4(03), 148-159. https://doi.org/10.29040/jiei.v4i03.302

Rahman, A. F., \& Rochmanika, R. (2012). PENGARUH PEMBIAYAAN JUAL BELI, PEMBIAYAAN BAGI HASIL, DAN RASIO NON PERFORMING FINANCING TERHADAP PROFITABILITAS BANK UMUM SYARIAH DI INDONESIA. IQTISHODUNA, (0). https://doi.org/10.18860/iq.v0i0.1768

Rahmawati, D. (2017). Analisis Pengaruh Pembiayaan Mudharabah, Musyarakah, Murabahah dan Inflasi terhadap Profitabilitas (ROA) Bank Umum Syariah Di Indonesia Periode 2011-2015. UIN Syarif Hidayatullah, Jakarta.

Riyadi, S., \& Yulianto, A. (2014). PENGARUH PEMBIAYAAN BAGI HASIL, PEMBIAYAAN JUAL BELI, FINANCING TO DEPOSIT RATIO (FDR) DAN NON PERFORMING FINANCING (NPF) TERHADAP PROFITABILITAS BANK UMUM SYARIAH DI INDONESIA. Accounting Analysis Journal, 3(4). https://doi.org/10.15294/aaj.v3i4.4208

Riyanto, I. S., \& Asakdiyah, S. (2020). ANALISIS PENGARUH INFLASI, JUMLAH UANG BEREDAR, DAN PRODUK DOMESTIK BRUTO TERHADAP 
RETURN ON ASSET (ROA) BANK SYARIAH DI INDONESIA. Jurnal Fokus Manajemen Bisnis, 6(2), 132-143.

Sari, D. W., \& Anshori, M. Y. (2017). PENGARUH PEMBIAYAAN MURABAHAH, ISTISHNA, MUDHARABAH, DAN MUSYARAKAH TERHADAP PROFITABILITAS (STUDI PADA BANK SYARIAH DI INDONESIA PERIODE MARET 2015 - AGUSTUS 2016). Accounting and Management Journal, 1(1). https://doi.org/10.33086/amj.v1i1.68

Setiawan, U. N. A., \& Indriani, A. (2016). Pengaruh Dana Pihak Ketiga (DPK), Capital Adequacy Ratio (CAR), dan Non Performing Financing (NPF) terhadap Profitabilitas Bank Syariah dengan Pembiayaan sebagai Variabel Intervening. Diponegoro Journal of Management, 5(4), 121-131.

Setyowati, D. H. (2020). Pengaruh Efisiensi Operasional Terhadap Return on Assets Pada Bank Umum Syariah di Indonesia. Jurnal Masharif al-Syariah: Jurnal Ekonomi dan Perbankan Syariah, 4(2).

Sudarwantoro, Y. (2014). Analisis Pengaruh Pertumbuhan Dana Pihak Ketiga, Capital Adequacy Ratio, Net Interst Margin, Dan Non Performing Loan Terhadap Return On Assets Pada Bank Yang Terdaftar Di Bursa Efek Indonesia Tahun 2007-2012. eProceedings of Management, 1(3), 1-24.

Suryanto, D. A., \& Susanti, S. (2020). Analisis Net Operating Margin (NOM), Non Performing Financing (NPF), Financing to Debt Ratio (FDR) dan Pengaruhnya Pada Efisiensi Perbankan Syariah di Indonesia. Jurnal Riset Akuntansi dan Keuangan, 8(1), 29-40. https://doi.org/10.17509/jrak.v8i1.19331

Suwiknyo, D. (2016). Analisis Laporan Keuangan Perbankan Syariah. Yogyakarta: Pustaka Pelajar.

Umam, K., \& Utomo, S. B. (2016). Perbankan Syariah Dasar-Dasar dan Dinamika Perkembangan di Indonesia. Jakarta: Raja Grafindo Persada.

Wahyuningsih, I. (2019). Menakar Dampak Pembiayaan Mudharabah dan Musyarakah terhadap Profitabilitas Return on Assets PT Bank Muamalat Indonesia Tbk. AlMashrafiyah: Jurnal Ekonomi, Keuangan dan Perbankan Syariah, 3(1).

Wardiyah, M. L. (2019). Pengantar Perbankan Syariah. Bengkulu: Pustaka Setia.

Widayati, N. (2016). Analisis Pembiayaan Mudharabah dan Musyarakah, Pembiayaan Murabahah, Penempatan pada Bank Indonesia, Capital Adequancy Ratio (CAR), dan Financing To Deposit Ratio (FDR) terhadap Tingkat Distribusi Bagi Hasil Bank Umum Syariah. Ekonomi Bisnis, 24(1).

Widiawati, W. (2019). PENGARUH NON PERFORMING FINANCING (NPF) TERHADAP NET OPERATING MARGIN (NOM) DI BANK BRI SYARI'AH PERIODE TAHUN 2014-2017. AKSY: Jurnal Ilmu Akuntansi Dan Bisnis Syariah, 1(1), 37-48. https://doi.org/10.15575/aksy.v1i1.4310

Widyawati, G. N. (2017). Pengaruh CAR, NPF, OER, PPAP, NOM terhadap Profitabilitas (ROA) pada Bank Umum Syariah Periode 2010-2015. UNY, Yogyakarta. 